\title{
Eco-imperialism and environmental justice
}

\section{Nygren, Anja}

Routledge

2013

Nygren , A 2013 , Eco-imperialism and environmental justice . in S Lockie , D A Sonnenfeld \& D R Fischer (eds), Routledge International Handbook of Social and Environmental Change . Routledge International Handbooks, Routledge , London , pp. 58-69 .

http://hdl.handle.net/10138/231402

acceptedVersion

Downloaded from Helda, University of Helsinki institutional repository.

This is an electronic reprint of the original article.

This reprint may differ from the original in pagination and typographic detail.

Please cite the original version. 


\section{Eco-Imperialism and Environmental Justice}

\section{Anja Nygren}

In recent years, environmental justice has become an important framework for the analysis of diverse environmental conditions and a powerful catalyst for popular mobilization in different parts of the world. Growing numbers of activists, scholars and policymakers refer to the framework of environmental justice when trying to understand the multiple concerns and claims over environmental degradation, resource rights, food security, climate change, local environmental knowledge, and other environmental issues (Carruthers 2008). In this rapidly evolving field, discourses related to eco-imperialism are gaining popularity, especially when exploring the disproportionate impact of environmental degradation on the lives of poor communities and ethnic minorities in the Global South.

This chapter aims to provide an overview of environmental justice as both a framework for the analysis of environmental concerns, and a discourse for political action. The main focus will be on the multifaceted links between the critique of eco-imperialism and the struggles over environmental justice in the Global South. As Joan Martínez Alier (2009) remarks, environmental issues are not just a matter of academic inquiry, or a luxury of the rich. They are deeply woven into the everyday lives and livelihoods of people, and their appreciation and practice of justice. The first section explores environmental justice and eco-imperialism as conceptual issues. The second section provides a brief introduction to the theoretical discussions on environmental justice, and illustrates the ways this framework has been used as an approach for interpreting diverse environmental concerns. The third section provides examples of socio-environmental movements that have used eco-imperialism and environmental justice as a political discourse and a means of popular mobilization in the struggle for justice and equity. By drawing on lessons from different parts of the world, it illustrates the multiple ways in which environmental justice activists articulate issues of justice. The fourth section deals with the growing transnationalization of environmental justice movements and the diverse tactics adopted by them in different socio-political and 
cultural contexts. Insofar as the notions of eco-imperialism and environmental justice highlight questions of distribution, participation, conflict, and equity, they provide a broad but helpful framework for understanding the variety of environmental mobilizations taking place in different parts of the world.

\section{Conceptual issues}

Both the academic and activist literature surrounding eco-imperialism and environmental justice utilize a number of conceptions of justice. In brief, 'environmental justice' refers to a socio-spatial distribution and recognition of environmental benefits and burdens within human populations, while 'ecological justice' focuses on the relationship between human beings and the rest of the natural world (Baxter 2005). This distinction is, however, not clearcut. Several scholars have recently called for the formulation of a broader approach that would combine issues of environmental and ecological justice (Agyeman 2006 and Scholsberg 2007). Environmental justice as a concept, emerged in the United States in the early 1980s, when certain African American, Latino, and Native American communities affected by industrial pollution began to protest against environmental racism (Bryant 2003 and Bullard 2000). Many environmental justice scholars make particular reference to the civil rights activists of Warren County, North Carolina, who organized themselves to stop the dumping of soil contaminated with hazardous materials in areas with a high proportion of African Americans. This prompted the launch of the environmental justice movement, which adopted civil rights and social justice approaches to environmental concerns. Shortly thereafter, environmental activists began to recognize similar struggles around the world (Mohai et al. 2009).

Rather than considering the environmental justice movement as a US or a Northern phenomenon which then spread to the Global South, we should pay attention to the diverse claims for environmental justice that have unfolded in different parts of the world, along with the social context in which they are grounded (Carruthers 2008). As Newell (2008: 51) remarks, there is a long history of environmental justice struggles around the world; it is more that these struggles have not always been framed in terms of environmental justice by Western observers. This especially concerns many Southern struggles, in which environmental justice is only one organizing principle among many issues, including 
indigenous rights, food security, human rights and democracy. In recent years, increasingly visible environmental justice campaigns have emerged in different parts of the world. This phenomenon is partly the result of the publicity given to environmental issues in contemporary development discourses and policies. Another impetus has been the increase of environmental awareness and public advocacy of environmental justice among different actors in civil society.

The discussion of environmental justice has close links to the discourse of 'eco-imperialism', which refers to the forceful imposition of Northern environmental views on the Global South. The debate over eco-imperialism arose from criticism of historical explanations of European colonization of the rest of the world in environmental terms. A popular example of such views may be found in Alfred Crosby's (1986) Ecological Imperialism: The Biological Expansion of Europe, 900-1900 which explains European control over the so-called New World in terms of the introduction of plants, animals and diseases to settler colonies. Corresponding ideas characterize Jared Diamond's (2005) bestseller Collapse: How Societies Choose to Fail or Succeed, in which bio-geographical factors such as the shape of the continents and the distribution of domesticable plants and animals are considered as the leading factors for Western European domination of other societies from the $16^{\text {th }}$ to $19^{\text {th }}$ century. Although Diamond claims that Western imperialism did not arise because of racial or cultural superiority, his analyses have been criticized for undertones of eco-imperialism. According to Blumer (2006) and Demeritt (2005), among others, Diamond uses overpopulation and environmental carrying capacity as the main factors to validate his Eurocentric view of world history, while largely ignoring analysis of changes in political economy.

Recently, many Southern researcher-activists have argued that eco-imperialistic views of the environment place the well-being of nature above the well-being of human populations, particularly at the margins of the Global South. Ramachandra Guha (1990) has claimed that Northern conservationists value the protection of endangered species more than the wellbeing of local people. Indeed, thousands of local inhabitants have been removed from their traditional lands to make way for protected areas dedicated to the preservation of nature and recreation for Northern tourists (Neumann 1998). Such agendas overlook questions that are crucial for Southern environmental movements, such as the struggle for territorial rights and the defence of local livelihoods. As Tim Ingold (2000) and James Carrier (2004) note, for 
many indigenous peoples and Southern communities, the environment is not a distinct object of protection separate from human engagement. In contrast, it is a sphere of life activity and a place where one dwells, works, and makes a living. On this basis, many Southern environmental justice groups question how campaigning for nature protection can be carried out without taking into account issues of social (in)equality and (under)development. These groups reject the one-sided approach of wilderness protection and seek to integrate issues of environmental conservation with local livelihoods. At the same time, they criticize Northern conservationists' tendency to reinvent indigenous peoples as noble stewards of pristine nature (Conklin and Graham 1995). Corresponding issues have been raised concerning global patterns of resource extraction. According to Arturo Escobar (2001, 2008), the Northern capitalist conception of nature produces a view of the natural environment as a realm to be appropriated through commodification and control. By aiming to break down the conventional boundary between nature and culture, Escobar emphasizes multiple constructions of nature and diverse modes of knowing about the environment. He argues for embedding questions of environmental justice within a broader framework of social justice, where the issues of whose resources are being exploited, whose knowledge is being appropriated, and what kinds of environmental and social costs local people have to bear in the name of a form of development from which they rarely benefit, are the crucial points of examination.

What is common to both the critique of eco-imperialism and the struggle for environmental justice is the search for alternatives to Northern-driven development models. In his book EcoImperialism: Green Power, Black Death, Paul Driessen (2005) argues that present-day ecoimperialists are similar to European imperialists of the $17^{\text {th }}$ century in that they attempt to keep developing countries poor for the benefit of the developed world. According to Driessen, radical environmental activists have become inflexible in their demands for environmental protection and insensitive to the needs of the billions of people who lack food, health-care and other basic necessities. Driessen criticizes Northern environmentaldevelopment models for having caused poverty and suffering in the Global South and urges developing countries to generate sustainable strategies for endogenous development, without dependency on foreign aid.

Correspondingly, Joan Martinez Alier (2002 and 2009) remarks that Northern economic accounting systems overlook indigenous concepts for valuing the environment, such as 
territorial rights, cultural attachment to the land, and other non-monetary values. The loss of people's place-based livelihoods and identities in Nigeria because of extensive oil extraction, or the destruction of the mangrove forests in Honduras to make way for export-driven shrimp production thus cannot be simplified to the issue of economic compensation (Schröeder 2000 and Watts 2004). According to Martinez Alier (2009), when poor people campaign for environmental protection, it is not because they are professional environmentalists but because their livelihoods are threatened. Crucial to this kind of "environmentalism of the poor' is the logic of a moral economy which is incompatible with the profit-based extraction of oil, minerals, wood and agro-fuels practised by corporations at the commodity frontiers (Martínez Alier 2009: 1111)

Whether such an environmentalism of the poor exists, and whether it can counteract the depletion of natural resources at the hands of big business, is a moot point even among those criticizing eco-imperialism and arguing for global environmental justice. As Peet et al. (2010) note, Northern and Southern views of nature are in themselves too heterogeneous to allow for strict categorizations. Most environmental justice scholars today agree that concepts of justice are hybrid and contested. It is not possible to consider every environmental conflict an issue of environmental justice, nor can every environmental justice issue be explained in terms of environmental conflict (Lockie 2009 and Pellow and Brulle 2005). The initial focus on racism in the conceptualization of environmental justice has recently shifted towards more nuanced views of the relationship between race, class, ethnicity, and other forms of social difference including gender and intergenerational justice (Buckingham and Kulcur 2009).

\section{Theoretical orientations}

As the movements that organize around environmental justice articulate diverse notions of justice it is little wonder that the theoretical approaches used to explain them are also pluralistic. Traditionally, the distributional aspect of justice has dominated environmental justice thinking. Scholars relying on the ideas of John Rawls (1971) have focused on the questions of who benefits from environmental resources and who bears the environmental and social costs (Dobson 1998). By examining the controversial use of land, such as the location of hazardous waste sites and polluting industrial facilities in socially marginalized areas, these studies have demonstrated that parcels of land are not simply empty fields 
awaiting human action. Rather, land is linked to specific interests and power relations (Bullard 2000). In recent years, the distributional aspect of environmental justice has expanded to better capture articulations of justice in everyday life. As Walker (2009) notes, environmental injustice does not arise simply from inequalities in the spatial distribution of risk; it is also a question of how they interact with unevenness in the social distribution of vulnerability and wellbeing.

Mark Pelling's (2003) study of urban flooding in Guyana provides an interesting example of how the spatial distribution of inequality interacts with social patterns concerning who is most vulnerable to impacts of flooding and how this vulnerability is produced for different people and places. Although risks might be similar, people do not experience or cope with them in the same way. This observation extends to the unevenness of psychological and social impacts. In the case of floods, a series of contributory factors to vulnerability need to be considered such as access to insurance, pre-existing health problems, availability of the resources needed to recover, and the effectiveness of authorities' responses to the emergency (Bickerstaff and Walker 2003). Pelling (2003) argues the majority of the urban poor in Southern cities live in areas (often informal or 'squatter' settlements with poor planning and services) in which they are exposed to a heightened level of environmental risk. The lack of political will to apply risk prevention strategies in 'shantytowns' stereotyped as the source of various social ills and health hazards creates a vicious circle of poor livelihood options, increasing vulnerability and further environmental degradation. In this light, the outcomes of injustice cannot be reduced to the issues of who lives in areas prone to flooding or how they came to live there; people's different experiences of vulnerability are also important.

To take account of this point, theorists have sought to complement the distributive approach with additional conceptual approaches to environmental justice. Researchers such as Iris Young (1990), Nancy Fraser (1997), and Axel Honneth (2001) have argued that justice must also address the processes that construct and legitimize practices of misdistribution, including both individual and social recognition (i.e. respect for the dignity and status of others). Here, what is central is not only the psychological component of recognition but also structural asymmetries and the social position of those less well-off in distributional schemes (Fraser and Honneth 2003). In this respect, there is a rich body of research in anthropology, geography and development studies which questions eco-imperialist explanations of the causes and consequences of environmental problems in the Global South. Several scholars 
have demonstrated how dominant representations of Southern environmental problems, such as deforestation or soil erosion, construct hegemonic narratives of degradation with limited empirical evidence (Escobar 1995, Forsyth 2003 and Rocheleau et al. 1995). Correspondingly, in a study of an Argentine shantytown with high levels of pollution, Auyero and Swistun (2009) demonstrate how state officials, lawyers, and media reporters visiting the neighbourhood created a hegemonic narrative of a contaminated place and contaminated people. Admittedly, the residents were worried about the pollution. However, they were also preoccupied with many other matters such as poverty, high levels of unemployment and lack of public security. At the core of such misrecognition are institutional processes which devalue some people and places in comparison to others. Once certain communities get 'associated with trash', they become a 'natural' target for further unwanted land due to the attitude that marginal people live in a disorderly way and do not care for their environment (Pellow 2002: 38). This attitude then further limits official efforts to address the environmental problems in such places (Hastings 2009 and Leichenko and Solecki 2008).

Many contemporary justice theorists also highlight aspects of procedural justice, which has motivated initiatives for greater political participation and more authentic citizenship in issues such as environmental rights, occupational health and human rights (Barnett and Low 2004 and Schrader-Frezette 2002). Conventionally, scholars arguing for procedural justice have asserted that those who are most affected by environmental decisions should have a particular right to have their voices heard. However, as Walker (2009) points out, this raises the question of how to define those who are most affected and how to decide the area for which compensations should be negotiated when the impact of environmental disasters arguably extend far beyond the immediate locality. The dilemma of who is included, and who is not, is complex; as illustrated by negotiations over rights to indigenous knowledge (Schröder 2000). Recently, theorists of procedural justice have extended their views of procedural justice to include the interaction between people, ideas, and perspectives across different institutions and sectors of society. The degree to which transparent interaction is genuinely achieved is the crucial test of whether procedural justice has been realized (Walker 2009).

Nancy Fraser (2009), David Scholsberg (2004 and 2007), and Gordon Walker (2009) have been particularly influential in the conceptualization of justice as an integrated multidimensional phenomenon. To summarize, justice as distribution focuses on the socio-spatial 
distribution of environmental impacts and responsibilities. Justice as recognition emphasizes the ways in which people's status or merit is evaluated in comparison with others. Justice as procedure looks at inclusions and exclusions in environmental policies and decision-making. Additionally, David Scholsberg and David Carruthers (2010) have recently introduced a capabilities framework to better capture the communal dimensions of environmental justice. Based on the theories of Martha Nussbaum and Amartya Sen (1992), the capabilities framework emphasizes the socially differentiated opportunities people have to take command of their lives and the well-being of their communities. Collective experiences of justice are crucial for many Southern communities where the central question may not be how satisfied an individual is, or the level of resources she or he commands, but the capabilities of the community to renew itself and act collectively (Sen 2010). In short, the different approaches to justice demonstrate the multiple dimensions of the phenomenon, even if all these approaches might not be equally important on every occasion.

\section{Movements and strategies}

Analytical approaches to justice can demonstrate the ways in which environmental-social relations are characterized by dominance and contribute to consideration of the transformations available within different political contexts (Fraser 2009). However, as many environmental activists emphasize, issues of environmental injustice go beyond analytical thinking, as they have implications for people's everyday life and thus require direct engagement. The way to grapple with acute injustice is thus considered to be through political struggle and social mobilization, even if the distinction between analytical reflection and political practice is often blurred as the ideas move between activist, scholarly, and policy circles. Nevertheless, as Amartya Sen (2010: vii) notes, an important impetus for mobilization for many activists is:

not the realization that the world falls short of being completely just - which few of us expect - but that there are clearly remediable injustices around us which we want to eliminate.

Environmental justice movements, especially in the Global South, are usually characterized by a plurality of actors and agendas. Depending on the case, there may be environmental and 
human rights activists, small producers and rural workers, academic scholars and urban popular movements, women's associations, labour unions and indigenous movements involved in the struggle for environmental justice. The way justice claims are made also varies. This is partly because, as Harvey states (1996: 6), 'different socio-ecological circumstances imply different approaches to the question of what is or is not just'; partly because acts of claim-making are strategic. Movements typically employ heterogeneous conceptions of justice and change their agendas according to the conditions. In environmental justice struggles against the mining industry in West Africa, for example, environmental issues, labour rights, and social justice issues are interwoven, as it is a situation where hundreds of workers have died in accidents and of occupational illnesses, child labour is commonly used, and the minerals mined in war zones are often sold to finance insurgencies.

Another common characteristic of Southern environmental justice struggles is the incorporation of current concerns over injustice into a broader historical pattern of ecoimperialistic resource exploitation. The expansion of Northern market actors into Southern peripheries often brings the interests of global capital into conflict with local communities (Newell 2008). This issue is illustrated in the Mapuche Indians' struggle against the construction of hydroelectric dams and the granting of concessions to mining and timber companies in Chile. As Schlosberg and Carruthers (2010) note, the Mapuche articulated their concerns over justice as a critique of a neoliberalist development model that favours transnational corporations over the well-being of the native communities. Their disgust was clearly expressed by one of the Mapuche leaders when he claimed: 'We don't want your progress to rub out our culture' (cited in Scholsberg and Carruthers 2010: 27). Crucial to the Mapuche's protest is the resistance to the opening up of new areas for resource exploitation by taking advantage of ignorance about indigenous resource rights. In addition, there is controversy over the appropriation of indigenous knowledge. Here, the Mapuche conceptualize Northern intellectual property rights as a form of colonialism which overrides collective rights to knowledge. Similar issues have been highlighted by Di Chiro (2007) who explores how indigenous activists in different parts of the world criticize the ongoing 'genetization' of environmental issues. They consider this eagerness to commodify 'life itself' as a continuation of centuries-old patterns of eco-imperialism.

The unequal power relations that mediate control over environmental resources in many parts of the world complicate verification of the disproportionate impact of environmentally 
harmful activities on socially vulnerable people. Polluting industries often claim that isolating the impact of their activities is difficult as the populations concerned are also affected by suboptimal living conditions such as poor housing, malnutrition, neighbourhood crime, and psychological stress. The paucity of systematic environmental and public health data presents an additional constraint. Furthermore, industrial sectors are often reluctant to release information on their activities while governments may enforce environmental laws unevenly (Carruthers 2008). Another tactic employed by governments is to use consensus-forming techniques to shift politicized protests away from confrontation towards collaboration. In a situation where industries seek to avoid communities that are capable of mounting effective opposition, those communities with limited economic and political power become an easy target for interventions containing a high degree of uncertainty. This does not justify the argument that the poor are uninterested in environmental health and sustainability. According to Freidberg (2004), the small producers in Burkina Faso and Zambia who grow high-quality vegetables for European markets do have concerns about food safety and sustainable livelihoods. The question is more that in precarious living conditions, they cannot afford healthy consumption practices themselves.

Support for environmental justice movements has traditionally been weak in many countries. Formal spaces for environmental policy-making are more accessible for civil society organizations that are willing to support official development programmes, while groups that question the appropriateness of governmental policies and advance environmental justice claims find themselves excluded from the official decision-making process. When they are frustrated in this way, many of these groups adopt strategies of protest and resistance to strengthen calls for environmental justice and to contest development interventions that lure transnational corporations to Southern peripheries with promises of abundant natural resources, cheap labour and minimal environmental regulation (Newell 2008). Campaigns against transnational oil companies' extraction activities on contested lands in Bolivia and Ecuador provide an illuminating example of such struggles (Perreault and Valdivia 2008). Another example is provided by protests against genetically-modified crops in Brazil, India, and South Africa. Many environmental justice groups, in alliance with small farmers, are protesting against the deterioration of local livelihoods and food security, in a situation where 25 percent of the global food production is consolidated in the hands of ten multinational companies (Dicken 2007: 367-368 and Scoones 2008). 
In addition to calls for more equal distribution of environmental resources and political rights, many Southern environmental justice movements emphasize issues related to cultural identities, collective values, and symbolic relationships with nature. This is clear, for example, in the environmental justice movement '13 Pueblos', in Morelos, Mexico. For years, the communities participating in this movement have fought against plans by the municipal government and a private company to construct sanitary landfills and dumping grounds in their territories (Risdell 2010). In this battle, struggles over material conditions and cultural meanings are tightly intertwined. Local residents articulate claims over environmental rights and ecological sustainability alongside calls for the protection of traditional ways of life, respect for sacred sites, and the preservation of communal capabilities. At the same time, this struggle demonstrates that environmental justice movements are far from internally homogeneous. Diverse conceptions of justice and how that justice can be sought, together with complicated power relations, form part of the dynamics of many environmental justice movements. Categorical distinctions between local resistance and outside intervention are thus difficult to justify.

\section{Localized images - globalized alliances}

In recent years, environmental justice movements have become increasingly transnational. Interaction between different levels of activity, from local proximities to globalized arenas, is an important tactic used by many activists to gain wider attention to their plight (Borras et al. 2008 and Roberts 2007). When the under-privileged in the Global South can demonstrate that they suffer from environmental hazards caused by the privileged of the North, the claims for justice sometimes gain particular weight (Gedicks 2009). In campaigns against the massive transfer of hazardous waste products from the North to Southern peripheries, activist groups have strategically presented the waste as the rubbish of the rich dumped in the backyards of the poor. Similarly in the electronics industry, where production workers are exposed to many harmful chemicals, environmental justice activists have campaigned against the high level of inequality in global networks of production, consumption and responsibility. In this way, they have succeeded in changing some corporations' environmental strategies and improving national and international legislation to address the worst excesses of electronic waste. Some activists have also been able to pressure transnational companies into recycling their electronics at the end of the products' lifecycle and to reduce the use of toxic inputs in 
their production processes (Smith et al. 2006).

Correspondingly, in negotiations over climate policies, environmental justice advocates have stressed that resilience to climate change is unequally distributed. This includes who causes the problem, who suffers most, who is expected to act, and who has the resources to do so (Ikeme 2003 and Roberts and Parks 2007). Many advocates also point out that global production and consumption networks do not respect territorial boundaries, and thus the most challenging environmental justice issues today incorporate transnational claims, which clearly demonstrates that even the remotest corners of the world are interconnected (Scholte 2005: 75-84).

In such fields of transcultural encounter, local forms of environmental consciousness mingle with global symbolic politics. Community identities and local environmental knowledge are often used as key symbols to promote campaigns where localized struggles over environmental justice are linked to transnational advocacy networks in order to gain more visibility and wider reach than a single movement could achieve on its own. The challenge in such alliances is often how to integrate the diverse interests involved in socially meaningful ways. According to Conklin and Graham (1995), alliances between Amazonian Indians and international environmentalists, for example, are often founded on the assertion that native peoples' environmental perceptions are consistent with Northern conservationist principles, where the Indians are represented as 'guardians of forest' and 'people dwelling in nature, according to nature'. Such images undermine both the complexity of the Indians' way of life and their priorities for environmental justice. In fact, what many native groups are seeking from such alliances is better recognition of their territorial rights, while environmentalists are looking for Indians to provide a human face for their biodiversity conservation agenda and legitimacy for their engagement in Southern environmental politics, which could otherwise be interpreted as a form of eco-imperialism. There is a risk that the Indians are accepted as useful partners in such networks only to the extent that they conform to Northern images of what constitutes an authentic conservationist. It is clear that more analysis is needed to better understand the promises and pitfalls offered by the transnationalization of environmental justice struggles.

In regard to environmental justice, both academic and public attention has focused often on those movements that have achieved media exposure or that have been successful in 
confronting the environmental threats affecting them. This is evident, for example, when comparing the attention paid to indigenous versus non-indigenous environmental struggles in the tropics. The way tropical forest-dwellers are often portrayed is based on a sharp dichotomy between those who are considered environmentally noble and those who are not. Indigenous peoples conforming to what is perceived as a traditional way of life are essentialized as peoples of simplicity and environmental wisdom. Non-indigenous peasants (or peasants who have simply lost or abandoned obvious markers of indigeneity) are portrayed as rootless, corrupted and lacking in environmental knowledge. Indigenous movements whose agendas for local cultural revitalization can be linked to global strategies for tropical conservation are often privileged over the struggles of poor peasants on the degraded agricultural frontiers. As Nygren (2004) shows, this selective attention limits the ability of non-indigenous forest-dwellers involved in land conflicts and suffering from political-economic marginalization and human-rights violation to gain access to transnational advocacy networks and global media.

To fully understand the heterogeneity of environmental justice concerns, it is important to pay attention not only to those battles with visible protests and confrontations but also to fragmented concerns with latent tensions and hidden forms of resistance. Jordi Diez and Reyes Rodríguez (2008) draw important lessons from the everyday forms of environmental justice important to a Mexican community subjected to serious health hazards from a polluting chemical enterprise. Their study demonstrates how institutional and social barriers can seriously constrain open mobilization for environmental justice. However, when periods of uncertainty and abnormality do emerge, destabilizing hegemonic interpretations of justice and allowing previously subordinated interpretations to make their way into public debate, there is much to be learned (Fraser 2009). More attention is needed to the fact that the main target of environmental justice activism has conventionally been transnational companies likely to be vulnerable to attacks on their global public image and, therefore, to be influenced by transnational organizing. There is little evidence that small and medium-sized domestic firms automatically operate in more environmentally sustainable and socially just ways, and thus no reason they should be spared the analytical and political gaze of environmental justice (Newell 2008: 66-67).

David Schlosberg has explained the transnational fluidity of environmental justice movements by likening them to a rhizome, as such movements sprout underground in various 
directions, and connect in ways that are not easily visible from above (Scholsberg 1999: 96, 120). Correspondingly, Tom Connor (2004) demonstrates how environmental justice groups and anti-sweatshop movements have been successful in persuading transnational corporations in the clothing and footwear industry to better respect environmental regulations and labour rights, through the strategies of scattered campaigns and mobile multi-scale networks. By dividing and merging, proliferating and contracting, without sharing allegiance to a particular organizational form or strategy of action (Keck and Sikkink 1998: 5), these movements have been able to raise effective campaigns without the risk of the entire movement becoming the target of oppression. In contrast to the 1990s, when most such campaigns originated in Northern organizations, today an increasing number of initiatives stem from Southern groups of justice activists, with logistic and financial support from sympathetic transnational networks.

\section{Conclusion}

This chapter has analyzed eco-imperialism and environmental justice as frameworks for analytical interpretation and as catalysts for social movements and political mobilization in different parts of the world. The critique of Northern-driven environmental-development models commonly presented both in the environmental justice literature and in circles contesting eco-imperialistic ideologies makes these concepts particularly useful for interpreting the diversity of environmental justice concerns in the Global South. As a phenomenon, environmental justice has a long history. For decades, there have been myriad forms of environmental mobilization and struggle in different parts of the world, even if those struggles have not always been framed in terms of environmental justice. Over the last decade, there has been a significant broadening in the academic and public understanding of the ways in which environmental issues, political rights, cultural values, and social justice matters are intertwined with environmental justice struggles, especially in the Global South.

Today, many scholars emphasize the fact that environmental justice is a complex concept which must be understood from the viewpoint of several interrelated strands - distribution, recognition, representation, and capabilities - to gain a fuller understanding of the different perceptions, scopes and meanings involved in this phenomenon in different circumstances. Such multi-dimensional approaches to justice incorporate the concept of inequity in the 
distribution of environmental goods and bads, together with a range of issues concerning recognition, participation, and community-based capabilities. The environmental justice framework acts as a catalyst for social mobilization and political struggle and challenges the conventional forms of environmental policy-making by highlighting environmental struggles as disputes over material resources and cultural meanings. The multiplicity of environmental justice concerns and claims in different environmental, socio-cultural and political-economic circumstances demonstrates the heterogeneity and hybridity of environmental justice struggles, especially in the Global South. While globalization has brought new threats and uncertainties to the livelihoods of the Southern poor, it has also prompted new forms of mobilization and organization in order to gain wider attention to local demands for justice. Numerous Southern environmental justice movements have established strategic alliances with transnational advocacy networks concerned with issues of global environmental justice.

\section{References}

Agyeman, J. (2006) Sustainable Communities and the Challenge of Environmental Justice. New York: New York University Press.

Auyero, J. and Swistun, D. A. (2009) Flammable: Environmental Suffering in an Argentine Shantytown. Oxford: Oxford University Press.

Barnett, C. and Low, M. (eds.) (2004) Spaces of Democracy: Geographical Perspectives on Citizenship, Participation and Representation. London: Sage.

Baxter, B. (2005) A Theory of Ecological Justice. London: Routledge.

Bickerstaff, K. and Walker, G. (2003) 'The Place(s) of Matter: Matter out of Place - Public Understandings of Air Pollution', Progress in Human Geography, 27, 1, pp. 45-67.

Blumer, M. (2006) 'Review of Collapse: How Societies Choose to Fail or Succeed (J. Diamond)', The Geographical Review, 96, 3, pp. 519-521.

Borras, S. M. Jr, Edelman, M. and Kay, C. (2008) 'Transnational Agrarian Movements: Origins and Politics, Campaigns and Impact', Journal of Agrarian Change, 8, 2-3, pp. 169-204.

Bryant, B. (2003) 'History and Issues of the Environmental Justice Movement', pp. 3-24 in: G. R. Visgilio and D. M. Whitelaw (eds.) Our Backyard: A Quest for Environmental Justice. Lanham: Rowman and Littlefield.

Buckingham, S. and Kulcur, R. (2009) 'Gendered Geographies of Environmental Justice', 
Antipode, 41, 4, pp. 659-683.

Bullard, R. D. (2000) Dumping in Dixie: Race, Class, and Environmental Quality. Boulder, CO: Westview Press.

Carrier, J. G. (2004) 'Introduction', pp. 1-29 in: J. G. Carrier (ed.) Confronting Environments: Local Understandings in a Globalizing World. Walnut Creek: AltaMira Press.

Carruthers, D. V. (2008) 'Introduction: Popular Environmentalism and Social Justice in Latin America', pp. 1-22 in: D. V. Carruthers (ed.) Environmental Justice in Latin America: Problems, Promise, and Practice. Cambridge, MA: MIT Press.

Conklin, B. and Graham, L. (1995) 'The Shifting Middle Ground: Amazonian Indians and Eco-Politics', American Anthropologist, 97, 4, pp. 695-710.

Connor, T. (2004) 'Time to Scale up Cooperation? Trade Unions, NGOs and the International Anti-Sweatshop Movement', Development in Practice, 14, 1-2, pp. 61-70.

Crosby, A. W. (1986) Ecological Imperialism: The Biological Expansion of Europe, 9001900. Cambridge: Cambridge University Press.

Demeritt, D. (2005) 'Perspectives on Diamond's Collapse: How Societies Choose to Fail or Succeed', Current Anthropology, 46, pp. S92-S94.

Diamond, J. (2005) Collapse: How Societies Choose to Fail or Succeed. New York: Penguin Books.

Di Chiro, G. (2007) 'Indigenous Peoples and Biocolonialism: Defining the 'Science of Environmental Justice' in the Century of the Gene', pp. 251-284 in: R. Sandler and P. C. Pezzullo (eds.) Environmental Justice and Environmentalism: The Social Justice Challenge to the Environmental Movement. Cambridge, MA: MIT Press.

Dicken, P. (2007) Global Shift: Mapping the Changing Contours of the World Economy. New York: Guildford Press.

Diez, J. and Rodríquez, R. (2008) 'Environmental Justice in Mexico: The Peñoles Case', pp. 161-179 in: D. V. Carruthers (ed.) Environmental Justice in Latin America: Problems, Promise and Practice. Cambridge, MA: MIT Press.

Dobson, A. (1998) Justice and the Environment: Theories of Distributive Justice. Oxford: Oxford University Press.

Driessen, P. (2005) Eco-Imperialism: Green Power, Black Death. New Delhi: Academic Foundation.

Escobar, A. (1995) Encountering Development: The Making and Unmaking of the Third World. Princeton: Princeton University Press. 
Escobar, A. (2001) 'Culture Sits in Places: Reflection on Globalism and Subaltern Strategies of Localization', Political Geography, 20, 2, pp. 139-174.

Escobar, A. (2008) Territories of Difference: Place, Movements, Life, Redes. Durham: Duke University Press.

Forsyth, T. (2003) Critical Political Ecology: The Politics of Environmental Science. London: Routledge.

Fraser, N. (1997) Justice Interrupts: Critical Reflections on the 'Postsocialist' Condition. London: Routledge.

Fraser, N. (2009) Scales of Justice: Reimagining Political Space in a Globalizing World. New York: Columbia University Press.

Fraser, N. and Honneth, A. (2003) Redistribution and Recognition? A Political-Philosophical Exchange. London: Verso.

Freidberg, S. (2004) French Beans and Food Scares: Culture and Commerce in an Anxious Age. Oxford: Oxford University Press.

Gandy, M. (2009) 'Planning, Anti-Planning and the Infrastructure Crisis Facing Metropolitan Lagos', Urban Studies, 43, 2, pp. 371-396.

Gedicks, A. (2009) Dirty Gold: Indigenous Alliances to End Global Resource Colonialism. Cambridge, MA: South End.

Guha, R. (1990) Environmentalism: A Global History. New York: Longman.

Harvey, D. (1996) Justice, Nature and the Geography of Difference. Oxford: Blackwell.

Honneth, A. (2001) 'Recognition or Redistribution: Changing Perspectives on the Moral Order of Society', Theory, Culture and Society, 18, 2-3, pp. 43-55.

Ikeme, J. (2003) 'Equity, Environmental Justice and Sustainability: Incomplete Approaches in Climate Change Politics', Global Environmental Change, 13, 3, pp. 195-206.

Ingold, T. (2000) The Perception of the Environment: Essays in Livelihood, Dwelling and Skill. London: Routledge.

Keck, M. and Sikkink, K. (1998) Activists Beyond Borders: Advocacy Networks in International Politics. Ithaca: Cornell University Press.

Leichenko, R. M. and Solecki, W. D. (2008) 'Consumption, Inequity, and Environmental Justice: The Making of New Metropolitan Landscapes in Developing Countries', Society and Natural Resources, 21, 7, pp. 611-624.

Lockie, S. (2009) 'Deliberation and Actor-Networks: The 'Practical' Implications of Social Theory for the Assessment of Large Dams and Other Interventions', Society \& Natural Resources, 20, 9, pp. 787-799. 
Martínez Alier, J. (2002) The Environmentalism of the Poor: A Study of Ecological Conflicts and Valuation. Cheltenham: Edwar Elgar.

Martínez Alier, J. (2009) 'Socially Sustainable Economic De-Growth', Development and Change, 40, 6, pp. 1099-1119.

Mohai, P., Pellow, D. and Roberts, J. T. (2009) 'Environmental Justice', Annual Review of Environment and Resources, 34, 16, pp. 405-430.

Newell, P. (2008) 'Contesting Trade Politics in the Americas: The Politics of Environmental Justice', pp. 49-74 in: D. V. Carruthers (ed.) Environmental Justice in Latin America: Problems, Promise, and Practice. Cambridge, MA: MIT Press.

Neumann, R. P. (1998) Imposing Wilderness: Struggles over Livelihood and Nature Preservation in Africa. Berkeley: University of California Press.

Nussbaum, M. and Sen, A. (1992) The Quality of Life. Oxford: Oxford University Press.

Nygren, A. (2004) 'Contested Lands and Incompatible Images: The Political Ecology of Struggles Over Resources in Nicaragua's Indio-Maíz Reserve', Society \& Natural Resources, 17, 3, pp. 189-205.

Peet, R., Robbins, P. and Watts, M. (2010) 'Global Nature', pp. 1-47 in: R. Peet, P. Robbins and M. Watts (eds.) Global Political Ecology. London: Routledge.

Pelling, M. (2003) 'Toward a Political Ecology of Urban Environmental Risk: The Case of Guyana', pp. 73-93 in: K. S. Zimmerer and T. J. Bassett (eds.) Political Ecology: An Integrative Approach to Geography and Environment-Development Studies. New York: Guilford Press.

Pellow, D. N. (2002) Garbage Wars: The Struggle for Environmental Justice in Chicago. Cambridge, MA: MIT Press.

Pellow, D. N. and Brulle, R. J. (2005) 'Power, Justice, and the Environment: Toward Critical Environmental Justice Studies', pp. 1-22 in: D. N. Pellow and R. J. Brulle (eds.) Power, Justice, and the Environment: A Critical Appraisal of the Environmental Justice Movements. Cambridge, MA: MIT Press.

Perreault, T. and Valdivia, G. (2010). 'Hydrocarbons, Popular Protest and National Imaginaries: Ecuador and Bolivia in Comparative Context', Geoforum, 41 5, pp. 689699.

Rawls, J. (1971) A Theory of Justice. Cambridge, MA: Harvard University Press.

Risdell, N. M. (2010) ‘ ¡No al relleno en Loma de Mejía!’ Conflicto, injusticia ambiental y movilización en Morelos. Paper presented at 'Congreso Nacional de Antropología Social y Etnología, Ciudad de México’, Mexico, 22-24 September. 
Roberts, J. T. (2007) 'Globalizing Environmental Justice: Trend and Imperative’, pp. 285-308 in: R. Sandler and P. C. Pezzullo (eds.) Environmental Justice and Environmentalism: The Social Justice Challenge to the Environmental Movement. Cambridge, MA: MIT Press.

Roberts, J. T. and Parks, B. C. (2007) A Climate of Injustice: Global Inequality, North-South Politics, and Climate Change. Cambridge, MA: MIT Press.

Rocheleau, D., Steinberg, P. E. and Patricia A. B. (1995) 'Environment, Development, Crisis, and Crusade: Ukambani, Kenya, 1890-1990', World Development, 23, 6, pp. 1037-1051.

Scholsberg, D. (1999) Environmental Justice and the New Pluralism: The Challenge of Difference for Environmentalism. Oxford: Oxford University Press.

Scholsberg, D. (2004) 'Reconceiving Environmental Justice: Global Movements and Political Theories', Environmental Politics, 13, 3, pp. 517-540.

Scholsberg, D. (2007) Defining Environmental Justice: Theories, Movements and Nature. Oxford: Oxford University Press.

Scholsberg, D. and Carruthers, D. (2010) 'Indigenous Struggles, Environmental Justice, and Community Capabilities', Global Environmental Politics, 10, 4, pp. 12-35.

Scholte, J. A. (2005) Globalization: A Critical Introduction, second edition. New York: Palgrave Macmillan.

Schrader-Frezette, K. (2002) Environmental Justice: Creating Equality, Reclaiming Democracy. Oxford: Oxford University Press.

Schröeder, R. (2000) 'Beyond Distributive Justice: Environmental Justice and Resource Extraction', pp. 52-64 in: C. Zerner (ed.) People, Plants and Justice: The Politics of Nature Conservation. New York: Columbia University Press.

Scoones, I. (2008) 'Mobilizing against GM Crops in India, South Africa and Brazil', pp. 147176 in: S. M. Borras Jr., M. Edelman and C. Kay (eds.) Transnational Agrarian Movements Confronting Globalization. Malden: Wiley-Blackwell.

Sen, A. (2010) The Idea of Justice. London: Penguin Books.

Smith, T., Sonnenfeld, D. A. and Pellow, D. N. (eds.) (2006) Challenging the Chip: Labor Rights and Environmental Justice in the Global Electronics Industry. Philadelphia, PA: Temple University Press.

Walker, G. (2009) 'Beyond Distribution and Proximity: Exploring the Multiple Spatialities of Environmental Justice', Antipode, 41, 4, pp. 614-636.

Watts, M. (2004) 'Resource Curse: Governmentality, Oil and Power in the Niger Delta, Nigeria', Geopolitics, 9, 1, pp. 50-80. 
Young, I. (1990) Justice and the Politics of Difference. Princeton: Princeton University Press. 